\title{
DESKRIPSI PELAKSANAAN ASURANSI USAHATANI PADI DI KELOMPOK TANI SUBUR MAKMUR DESA KARANGMEKAR, KECAMATAN KARANGSEMBUNG, KABUPATEN CIREBON
}

\author{
MUHAMMAD ESA PERTIBY KABAN*, KUSWARINI KUSNO \\ Program Studi Agribisnis Fakultas Pertanian Universitas Padjadjaran \\ Jl. Raya Bandung Sumedang KM.21, Sumedang, Jawa Barat. Telp: (022) 84288828 \\ *Email: Esapertiby@gmail.com
}

\begin{abstract}
ABSTRAK
Penelitian ini dilakukan di Kelompok Tani Subur Makmur Kabupaten Cirebon, Kecamatan Banjarsari, Desa Karangmekar. Kabupaten Cirebon merupakan salah satu kabupaten atau kota yang mengalami gagal panen dan telah mengikuti program pemerintah yaitu Asuransi Usahatani Padi (AUTP). Desa Karangmekar merupakan salah satu desa yang mendapatkan klaim asuransi terbesar se-Jawa Barat. Penelitian ini memiliki tujuan untuk mendeskripsikan pelaksanaan, kendala asuransi serta karakteristik dari petani Subur Makmur yang mengikuti asuransi pertanian. Salah satu cara untuk mengetahui pelaksanaan asuransi di Desa Karangmekar ialah dengan melihat kejadian di lapangan lalu melihat apakah sesuai dengan prosedur yang ditetapkan pada Pedoman Asuransi Usahatani Padi. Kendala yang dihadapi dan karakteristik petani dikategorikan menurut teori. Dari hasil penelitian, petani Subur Makmur mayoritas petani laki-laki berumur produktif, berpengalaman dalam usahatani, memilki 1 orang tanggungan keluarga, pendidikan terakhir hanya Sekolah Dasar, berpenghasilan menengah ke bawah, memiliki lahan sedang dan merupakan petani penyewapenggarap, memiliki alasan mengikuti AUTP karena kebutuhan keamanan. Pelaksanaan asuransi di Kelompok Tani Subur Makmur sudah berjalan sesuai dengan prosedur yang ditetapkan. Kendala teknis yang dialami yaitu petugas Jasindo kurang cepat melakukan peninjauan ke desa dan kendala ekonomi yang dihadapi ialah beberapa petani belum memiliki dana untuk membayar premi pada saat pendaftaran.
\end{abstract}

Kata Kunci: Asuransi Usahatani Padi, Kelompok Tani, Klaim Asuransi, Karakteristik Petani

\begin{abstract}
The research was conducted in the farmers group of Subur Makmur Karangmekar Village, Karangsembung Sub-District, Cirebon District. Cirebon was one of district which experienced in crop failure and has been participating the government programs namely Rice Farming Insurance or in Bahasa called Asuransi Usahatani Padi (AUTP). Karangmekar village was one of the villages that received insurance claim largest in West Java. This research has an objective to described the implementation, obstacles of the insurance, and the characteristics from the insurance participants. One way to find out the implementation of insurance in Karangmekar village was take a look at the incident and see if in accordance with the procedures set on guidelines insurance farming rice. Obstacles faced and characteristic of farmers are based on the theory. The result of the research, the majority of farmers Subur Makmur is a man and productive, have experiece in farming, final education of elementary school, middle low income, has a moderate land area, and are tenant farmers, the reason joined AUTP because the needs of security. The implementation of insuramce in the farmers Subur Makmur already in accordance with estabilished. The technical obstacles that experienced, officers Jasindo less rapid judicially to the village and economic obstacles faced there was some farmers did not have yet money to pay a premium at the time of registration.
\end{abstract}

Keywords: Rice Farming Insurance, the farmers, claim insurance, characteristic of farmers 


\section{PENDAHULUAN}

Sektor pertanian merupakan salah satu sektor yang memiliki peran penting dalam perekonomian nasional. Menurut Pasaribu (2014), secara teknis kegiatan usaha pertanian akan selalu dihadapkan pada resiko yang cukup tinggi, meliputi tingkat kegagalan panen yang disebabkan berbagai bencana alam, seperti banjir, kekeringan, serta serangan hama dan penyakit karena perubahan iklim global, di samping resiko tidak pastinya harga pasar.

Risiko gagal panen yang disebabkan oleh serangan OPT, kebanjiran dan kekeringan diberikan ganti rugi oleh pemerintah melalui asuransi pertanian. Di Indonesia, sejak tahun 1982-1998 telah tiga kali $(1982,1984,1985)$ dibentuk Kelompok Kerja Persiapan Pengembangan Asuransi Panen. Pada tahun 1999, pengembangan asuransi pertanian dicanangkan kembali. Pembahasan serius telah dilakukan, tetapi untuk melangkah ke tahap implementasi perlu dipertimbangan yang matang, dibutuhkan berbagai masukan untuk merumuskan kebijakan, strategi, program, perintisan, dan instrumen kelembagaan yang sesuai dengan strategi pengembangan (PSE-KP, 2009). Pada tahun 2013, dibuat Undang-Undang nomor 19 yang mengatur 2 (dua) hal pokok untuk memberdayakan dan melindungi petani (Septian, 2014). Pelaksanaan pilot project (proyek percontohan) dilaksanakan pada tahun 2012 hingga 2014, pelaksanaan pilot project dinilai cukup berhasil sehingga dapat dilanjutkan dengan pelaksanaan (Amran, 2017).

Pelaksanaan program asuransi ini dilaksanakan pada tahun 2015, program tersebut adalah Asuransi Usaha Tani Padi (AUTP) bekerjasama dengan perusahaan asuransi yaitu PT. JASINDO (Jasa Asuransi Indonesia) salah satu BUMN yang menangani asuransi umum dan kerugian. Program AUTP tersebut didasarkan pada Undang-Undang Nomor 19 Tahun 2013 tentang Perlindungan dan Pemberdayaan Petani (UUP3). Dalam regulasi tersebut, Pasal 39 ayat (1) dan (2) menyatakan bahwa sesuai dengan kewenangannya, pemerintah pusat dan pemerintah daerah memfasilitasi setiap petani menjadi peserta asuransi. Salah satu fasilitasi tersebut adalah bantuan pembayaran premi, bantuan tersebut berasal dari APBN dan/atau APBD. Ditindaklanjuti dengan Peraturan Menteri Pertanian No. 40 Tahun 2015 tentang Fasilitasi Asuransi Pertanian, tahun 20152019 merupakan tahap awal pengembangan kebijakan AUTP dan 
menjadi dasar pertimbangan implementasi kebijakan asuransi pertanian. (Amran, 2017).

Ganti rugi diberikan kepada peserta terdaftar AUTP apabila terjadi banjir, kekeringan dan atau serangan OPT yang mengakibatkan kerusakan tanaman padi yang dipertanggungkan dengan kondisi persyaratan yang tercantum padaPedoman Bantuan Premi (Dirjen PSP, 2018). Klaim AUTP tertinggi pada tahun 2017 berada di Kabupaten Cirebon dengan nilai klaim Rp 14.619.254.000,00 hal ini apabila dibandingkan dengan kabupaten/kota lainnya salah satunya yaitu Kabupaten Indramayu dengan nilai klaim sebesar Rp 10.896.346.800,00 hal ini berdasarkan data keseluruhan kabupaten atau kota di Jawa Barat yang diperoleh dari Dinas Hortikultura dan Tanaman Pangan Jawa Barat. Nilai klaim Kabupaten Cirebon sebesar Rp 14.619.254.000,00 merupakan akumulasi 16 kecamatan dari total 40 kecamatan yang ada.

Ganti rugi atas gagal panen yang dialami oleh petani yang akan digunakan sebagai modal kerja usahatani untuk pertanaman berikutnya (Dirjen PSP, 2018). Walaupun nilai klaim asuransi Kecamatan Karangsembung sebesar Rp 397.000.000 tertinggi ke-6 dibanding 16 kecamatan lain, diantaranya yaitu
Kecamatan Pangenan sebesar Rp 793.800.000 tertinggi ke-5 dan kecamatan dengan nilai klaim paling tinggi yaitu Kecamatan Kapetakan sebesar Rp 7.044.682.000 yang tertera pada data nilai klaim Kabupaten Cirebon, namun Kecamatan Karangsembung terdapat desa yaitu Desa Karangmekar dimana desa tersebut memiliki nilai klaim tertinggi Kabupaten Cirebon bahkan Provinsi Jawa Barat. Desa Karangmekar merupakan desa yang memiliki nilai klaim tinggi di Kabupaten Cirebon, hal ini bisa dilihat pada Tabel 2 nilai klaim AUTP di Desa Karangmekar berjumlah $\quad \mathrm{Rp}$ 259.200.000,00. Adanya perbedaan jumlah petani yang mendaftar dan yang menerima ganti rugi menjadi alasan mengapa penulis memilih topik penelitian yaitu pelaksanaan Asuransi Usahatani Padi, kendala yang dihadapi petani beserta karakteristik petani itu sendiri.

Penelitian ini bertujuan untuk mengetahui: (1) Karakteristik petani kelompok tani Subur Makmur yang menjadi peserta dan telah mendapatkanganti rugi gagal panen pada musim tanam April - Juli 2017, dan (2) Kendala apa saja yang dihadapi petani kelompok tani Subur Makmur dalam pelaksanaan Asuransi Usahatani Padi (AUTP). 


\section{METODE PENELITIAN}

Objek penelitian ini adalah bagaimana karakteristik petani dan kendala yang dihadapi petani dalam pelaksanaan AUTP. Penelitian ini dilaksanakan di kelompok tani Subur Makmur yang bertempat bertempat di Desa Karangmekar, Kecamatan Karangsembung, Kabupaten Cirebon. Desain penelitian yang digunakan pada penelitian ini adalah kualitatif dan kuantitatif.

Sumber data yang digunakan dalam penelitian ini adalah data primer dan data sekunder. Penelitian ini menggunakan teknik purposive sampling yaitu pengambilan sampel berdasarkan pertimbangan perorangan atau pertimbangan peneliti (Sudjana, 2002), dengan pertimbangan yaitu 69 orang petani Subur Makmur telah melaksanakan pendaftaran AUTP dan mendapatkan ganti rugi gagal panen. Pada saat melakukan penelitian, penulis hanya mendapatkan 33 orang petani dari 69 orang petani Subur Makmur. Dua orang informan untuk menunjang kebutuhan hasil penelitian.

Dalam penelitian ini memperoleh data yang diperlukan menggunakan beberapa teknik yaitu, studi literature, observasi dan dokumentasi, wawancara mendalam, kuisioner dan angket.

\section{HASIL DAN PEMBAHASAN}

\section{Karakteristik Petani}

Karakteristik Demografi, seperti yang sudah dijelaskan sebelumnya bahwa karakteristik demografi terdiri atas:

a) Umur, umur merupakan salah satu indikator untuk menentukan produktivitas kerja seseorang. Berdasarkan pengamatan dilapangan, petani Subur Makmur dibagi menjadi 3 kategori berdasarkan teori produktivitas kerja menurut BPS. Berikut umur petani yang menjadi peserta asuransi dan pernah mendapatkan klaim AUTP.

Tabel 1. Kategori Umur Petani Kelompok Subur Makmur

\begin{tabular}{clcc}
\hline No & Kategori Umur & $\begin{array}{c}\text { Jumlah } \\
\text { Petani } \\
\text { (orang) }\end{array}$ & $\begin{array}{c}\text { Persentase } \\
\text { (\%) }\end{array}$ \\
\hline 1 & $\begin{array}{l}0-14 \text { tahun } \\
\text { (Belum } \\
\text { produktif) }\end{array}$ & 0 & 0 \\
2 & $\begin{array}{l}15-64 \text { tahun } \\
\text { (Produktif) } \\
\text { 65 tahun ke atas } \\
\text { (Tidak } \\
\text { produktif) }\end{array}$ & 6 & 18,2 \\
\hline & Total & $\mathbf{3 3}$ & $\mathbf{1 0 0}$ \\
\hline
\end{tabular}

Berdasarkan data Tabel 1, dapat dilihat bahwa petani dengan ketegori produktif memiliki persentase jauh lebih besar dengan ketegori tidak produktif, hal ini bisa dikatakan bahwa mayoritas petani melakukan usahatani padi sawah pada umur yang sedang produktif.

b) Jenis Kelamin, berikut pembagian 
petani anggota Subur Makmur yang menjadi peserta asuransi menurut jenis kelamin.

Tabel 1. Petani Subur Makmur Berdasarkan Jenis Kelamin

\begin{tabular}{clcc}
\hline No & $\begin{array}{c}\text { Jenis } \\
\text { Kelamin }\end{array}$ & $\begin{array}{c}\text { Jumlah } \\
\text { (orang) }\end{array}$ & $\begin{array}{c}\text { Persentase } \\
(\mathbf{\%})\end{array}$ \\
\hline 1 & Laki-laki & 29 & 87,9 \\
2 & Perempuan & 4 & 12,1 \\
\hline & Total & $\mathbf{3 3}$ & $\mathbf{1 0 0}$ \\
\hline
\end{tabular}

Berdasarkan Tabel 2, mayoritas petani laki-laki sebagai anggota Subur Makmur yang menjadi peserta asuransi dengan besaran persentase 87,9 persen lebih besar dengan persentase petani perempuan. Hal ini sesuai dengan data mata pencaharian di Desa Karangmekar menyebutkan jumlah petani perempuan lebih sedikit daripada petani laki-laki.

c) Jumlah tanggungan keluarga, profil keluarga petani merupakan petani asli yang berdomisili di Desa Karangmekar yang pada umumnya mempunyai tanggungan keluarga yang telah menikah dan tercatat sebagai pemilik laha padi sawah (Tabel 3).

Tabel 2. Jumlah Tanggungan Keluarga

\begin{tabular}{cccc}
\hline No & $\begin{array}{c}\text { Tanggungan } \\
\text { Keluarga (orang) }\end{array}$ & $\begin{array}{c}\text { Jumlah } \\
\text { Petani } \\
\text { (orang) }\end{array}$ & $\begin{array}{c}\text { Persentase } \\
\text { (\%) }\end{array}$ \\
\hline 1 & 0 & 1 & 3 \\
2 & 1 & 13 & 39,4 \\
3 & 2 & 11 & 33,4 \\
4 & 3 & 8 & 24,2 \\
\hline & Total & $\mathbf{3 3}$ & $\mathbf{1 0 0}$ \\
\hline
\end{tabular}

Berdasarkan Tabel 3, dapat dilihat jumlah tanggungan mayoritas berjumlah 1 orang dengan persentase 39,4 persen, sedangkan 3 orang tanggungan dengan persentase 24,2 persen.

d) Pengalaman Kerja, Petani Subur Makmur mempunyai pengalaman yang bervariasi dalam usahatani padi dan juga pengalaman menjadi peserta AUTP di Desa Karangmekar.

Dikategorikan menurut Tulus (1992

Tabel 3. Pengalaman Petani Dalam Usahatani Padi

\begin{tabular}{clcc}
\hline No & Pengalaman & $\begin{array}{c}\text { Jumlah } \\
\text { Petani } \\
\text { (orang) }\end{array}$ & $\begin{array}{c}\text { Persentase } \\
\mathbf{( \% )}\end{array}$ \\
\hline 1 & $<6$ tahun & 6 & 18,2 \\
2 & $6-10$ tahun & 2 & 6,1 \\
3 & $>10$ tahun & 25 & 75,7 \\
\hline & Total & $\mathbf{3 3}$ & $\mathbf{1 0 0}$ \\
\hline
\end{tabular}

Petani yang menjadi peserta asuransi mayoritas melakukan usahatani lebih dari 10 tahun dengan persentase 75,7 persen, hal ini menunjukan bahwa petani padi Subur Makmur berpengalaman dalam usahatani hal ini disebabkan karena umumnya petani Subur Makmur melakukan usahatani secara turun menurun.

Pengalaman usahatani petani Subur Makmur terbilang berpengalaman, namun petani Subur Makmur baru mengikuti program asuransi pertanian. Hal ini sesuai dengan hasil wawancara dengan petani, ditunjukan pada Tabel 5. 
Tabel 4. Pengalaman Petani Menjadi Peserta AUTP

\begin{tabular}{ccc}
\hline $\begin{array}{c}\text { Pengalaman } \\
\text { Menjadi Peserta } \\
\text { AUTP }\end{array}$ & $\begin{array}{l}\text { Jumlah } \\
\text { Petani } \\
\text { (orang) }\end{array}$ & $\begin{array}{c}\text { Persentase } \\
\mathbf{( \% )}\end{array}$ \\
\hline 1 kali musim tanam & 1 & 3 \\
2 kali musim tanam & 12 & 36,4 \\
3 kali musim tanam & 6 & 18,2 \\
4 kali musim tanam & 9 & 27,3 \\
5 kali musim tanam & 0 & 0 \\
6 kali musim tanam & 5 & 15,1 \\
\hline Total & $\mathbf{3 3}$ & $\mathbf{1 0 0}$ \\
\hline
\end{tabular}

Berdasarkan Tabel 5, petani yang menjadi peserta asuransi dari awal pelaksanaan di Desa Karangmekar terhitung mulai tahun 2015 hanya berjumlah 5 orang petani dengan persentase sebesar 15,1 persen, sedangkan jumlah paling banyak yaitu petani yang menjadi peserta AUTP sebanyak 2 kali musim dengan persentase 36,4 persen dari 33 orang petani. Menurut hasil wawancara, petani anggota Subur Makmur secara keseluruhan baru pertama kali mengetahui asuransi pertanain sejak adanya sosialisasi asuransi usahatani padi di Desa Karangmekar tahun 2015.

\section{Karakteristik Sosial Ekonomi}

(a) Tingkat pendidikan, Tingkat pendidikan seseorang dalam satu wilayah dapat menggambarkan potensi sumberdaya manusia dan kulitas tenaga kerja di wilayah tersebut. Tingkat pendidikan masyarakat merupakan salah satu pengentas kemiskinan. Semakin tinggi tingkat pengetahuan masyarakat, maka pola pikir masyarakat tersebut akan semakin kreatif dalam melakukan inovasi guna meningkatkan hasil usahanya. Berikut pembagian data yang diperoleh di tempat penelitian menurut Undang-Undang Nomor 20 Tahun 2003.

Tabel 5. Tingkat Pendidikan Petani

\begin{tabular}{clcc}
\hline No & $\begin{array}{c}\text { Tingkat } \\
\text { Pendidikan }\end{array}$ & $\begin{array}{c}\text { Jumlah } \\
\text { (orang) }\end{array}$ & $\begin{array}{c}\text { Presentase } \\
(\mathbf{\%})\end{array}$ \\
\hline 1 & SD/Sederajat & 24 & 72,7 \\
2 & SMP dan SMA & 9 & 27,3 \\
3 & Perguruan & 0 & 0 \\
& Tinggi & & \\
\hline & Total & $\mathbf{3 3}$ & $\mathbf{1 0 0}$ \\
\hline
\end{tabular}

Dapat dilihat pada Tabel 6, jumlah paling besar ialah petani yang hanya dengan tingkat pendidikan Sekolah Dasar yaitu berjumlah 24 orang dengan persentase sebesar 72,7 persen. Tingkat pendidikan petani Subur Makmur dikategorikan rendah, hal ini karena keterbatasan ekonomi untuk melanjutkan ke jenjang pendidikan yang lebih tinggi.

(b) Penghasilan Petani, Data penghasilan petani di bawah ini berdasarkan luasan lahan masing-masing petani Subur Makmur yang dikonversi ke dalam hitungan per bulan, dengan asumsi dalam satu kali musim tanam terdapat 4 bulan (Tabel 7). Tabel 7 merupakan kategori berdasarkan penghasilan per bulan menurut World Bank, dan untuk 
penghasilan setiap petani. Tabel 7 menunjukan bahwa mayoritas petani Subur Makmur memiliki penghasilan menengah ke bawah, dan untuk 6 orang memiliki penghasilan menengah dimana 6 orang tersebut memiliki luas garapan $2 \mathrm{Ha}$ dan termasuk kategori dalam petani berpengalaman dalam usahatani.

Tabel 6. Penghasilan Usahatani Petani

\begin{tabular}{lcc}
\hline \multicolumn{1}{c}{$\begin{array}{c}\text { Penghasilan } \\
\text { Usahatani } \\
\text { (Rp)/Bulan }\end{array}$} & $\begin{array}{l}\text { Jumlah } \\
\text { Petani } \\
\text { (orang) }\end{array}$ & $\begin{array}{c}\text { Persentase } \\
\text { (\%) }\end{array}$ \\
\hline $\begin{array}{l}<2,6 \text { juta (Menengah } \\
\text { ke bawah) }\end{array}$ & 27 & 81,8 \\
$\begin{array}{l}2,6 \quad \text { juta }-\quad 10 \quad \text { juta } \\
\text { (Menengah) } \\
>10 \text { juta (Menengah ke } \\
\text { atas) }\end{array}$ & 0 & 18,2 \\
\hline \multicolumn{1}{c}{ Total } & $\mathbf{3 3}$ & $\mathbf{1 0 0}$ \\
\hline
\end{tabular}

(c) Luas Lahan, dibagi ke dalam 3 kategori menurut Sajogyo, yaitu luas lahan sempit, sedang dan luas. Berikut luas lahan petani berdasarkan hasil wawancara kepada petani (Tabel 8).

Tabel 7. Luas Lahan Petani

\begin{tabular}{lcc}
\hline \multicolumn{1}{c}{ Luas Lahan (Ha) } & $\begin{array}{c}\text { Jumlah } \\
\text { Petani } \\
\text { (orang) }\end{array}$ & $\begin{array}{c}\text { Persentase } \\
(\%)\end{array}$ \\
\hline $\begin{array}{l}\text { Lahan sempit }(<0,5) \\
\text { Lahan sedang }(0,5-\end{array}$ & 0 & 0 \\
1) & 23 & 69,7 \\
Lahan Luas $(>1)$ & 10 & 30,3 \\
\hline \multicolumn{1}{c}{ Total } & $\mathbf{3 3}$ & $\mathbf{1 0 0}$ \\
\hline
\end{tabular}

Data Tabel 8 menunjukan bahwa petani Subur Makmur memiliki lahan dengan kategori sedang dengan persentase 69,7 persen, hal ini berdasarkan teori luas lahan menurut Sajogyo yang menyatakan luas lahan berkisar 0,5 ha hingga $1 \mathrm{Ha}$ termasuk kategori petani dengan luasan lahan sedang. Sedangkan petani dengan luas garapan lebih dari 1 ha dikategorikan lahan luas, yang dimana petani Subur Makmur terdapat 10 orang petani yang dikategorikan petani lahan luas. Meskipun 10 petani dikategorikan petani lahan luas dengan lebih dari 1 ha, dari 10 petani tersebut tidak ada yang menggarap dari 2 ha, hal ini sesuai dengan ketentuan kriteria calon peserta Asuransi Usahatani Padi yang terdapat pada Pedoman AUTP.

(d) Status Penguasaan Lahan, Hasil wawancara pada penguasan lahan ditunjukan pada Tabel 19, dilihat bahwa 27 petani Subur Makmur dari 33 petani merupakan petani yang melakukan sewa kepada pemilik lahan untuk dibudidayakan, dan pada umumnya lahan yang disewa merupakan tanah bengkok dalam arti lain ialah tanah yang menjadi hak aparatur Desa Karangmekar yang diperuntukan sebagai gaji aparatur desa. Meskipun petani sebagai penyewa, pada saat pendaftaran AUTP tetap mendaftar atas nama petani yang menyewa lahan tersebut, begitupun petani sebagai penggarap. Hal ini berdasarkan ketentuan pesrta calon AUTP, petani penggarap bisa 
mendaftarkan atas nama petani itu sendiri dengan membayar premi yang ditentukan dengan luasan lahan garapan tidak lebih dari $2 \mathrm{Ha}$.

Tabel 8. Status Penguasaan Lahan Petani

\begin{tabular}{|c|c|c|c|}
\hline $\begin{array}{l}\text { Status Penguasan } \\
\text { Lahan }\end{array}$ & & $\begin{array}{c}\text { Jumlah } \\
\text { Petani } \\
\text { (orang) }\end{array}$ & $\begin{array}{c}\text { Persentase } \\
(\%)\end{array}$ \\
\hline $\begin{array}{l}\text { Pemilik } \\
\text { Pengggarap }\end{array}$ & - & 6 & 18,2 \\
\hline $\begin{array}{l}\text { Penyewa } \\
\text { Penggarap }\end{array}$ & - & 27 & 81,8 \\
\hline Penggarap & & 0 & 0 \\
\hline Total & & 33 & 100 \\
\hline
\end{tabular}

(e) Alasan petani mengikuti asuransi usahatani padi, Asuransi Usahatani
Padi sudah ada di Desa Karangmekar sejak tahun 2015, dan sudah ada 5 petani Subur Makmur yang ditunjukan pada Tabel 13 dimana petani tersebut mendaftar sebagai peserta AUTP dari awal tahun 2015. Berdasarkan Tabel 10 bisa dilihat bahwa alasan petani diklasifikasi menurut tingkatan motivasi menurut Maslow (2010). Tingkat motivasi tertinggi ialah kebutuhan aktualisasi diri dan terendah ialah kebutuhan fisiologis.

Tabel 9. Tingkatan Alasan atau Motivasi Petani Menurut Maslow

\begin{tabular}{llcc}
\hline \multicolumn{1}{c}{ Tingkatan Motivasi } & \multicolumn{1}{c}{ Alasan Petani } & $\begin{array}{c}\text { Jumlah Petani } \\
\text { (orang) }\end{array}$ & Persentase (\%) \\
\hline Kebutuhan Keamanan & Memberikan Rasa Aman & 15 & 45,5 \\
Kebutuhan Sosial & Ajakan dari Petani Lain & 7 & 21,2 \\
Kebutuhan Penghargaan & Keinginan Diri Sendiri/Bermanfaat & 11 & 33,33 \\
(Diri Sendiri) & bagi Diri Sendiri & $\mathbf{3 3}$ & $\mathbf{1 0 0}$ \\
\hline
\end{tabular}

Hasil dari Tabel 10 berdasarkan alasan yang diungkapkan oleh petani. Sebanyak 15 petani berada pada posisi ke-4 menurut hirarki motivasi Maslow (2010) yaitu kebutuhan kemanan, petani tersebut beralasan mengikuti AUTP karena memberikan rasa aman akan modal ketika terjadi gagal panen nantinya. Satu tingkat di atas kebutuhan keamanan yaitu kebutuhan sosial, terdapat 7 orang petani, beralasan mengikuti AUTP karena ada ajakan dari petani lain. Sedangkan 11 orang petani lainnya termasuk ke dalam tingkatan yang ke-2, kebutuhan penghargaan diri sendiri, tingkatan yang lebih tinggi dibandingkan dengan tingkatan yang lain, petani di tingkatan ini beralasan bahwa mengikuti AUTP berdasarkan kebutuhan dan keinginan mereka sendiri. Semakin tinggi tingkatan pada hirarki semakin tinggi pula motivasi yang dimiliki petani untuk memenuhi kebutuhannya, dalam hal ini ialah kebutuhan untuk menjadi peserta Asuransi Usahatani Padi. Walaupun demikian, salah satu petani menjelaskan bahwa mendaftarkan diri sebagai peserta asuransi bukan berarti petani tersebut 
berharap gagal panen dan meneriman ganti rugi dari Jasindo, melainkan untuk berjaga-jaga apabila petani mengalami gagal panen sehingga ganti rugi tersebut bisa digunakan kembali untuk keberlanjutan usatani petani.

\section{Kendala-kendala}

Pelaksanaan

\section{Asuransi Usahatani Padi}

Pada tahun 2015, program asuransi usahatani padi ini dilaksanakan di Desa Karangmekar, dimulai dengan adanya sosialisasi di balai desa mengundang kelompok tani besrta anggotaanggotanya. Pada pelaksanaanya terdapat tahap-tahap yang harus dilakukan oleh petani mulai dari proses pendaftaran yang dilakukan secara kolektif hingga pemberian ganti rugi atas gagal panen yang dialami petani. Berdasarkan hasil wawancara yang dilakukan oleh penulis, terdapat hambatan atau kendala yang dihadapi oleh peserta asuransi yaitu petani Subur Makmur dalam pelaksanaan asuransi usahatani padi periode musim tanam April - Juli 2017.

Pada pendaftaran asuransi usahatani padi, petani diminta untuk membayar premi swadaya sebesar Rp 36,000/Ha/Musim tanam yang seharusnya sebesar Rp 144,000/Ha/Musim tanam sebagai persyaratan menjadi peserta
AUTP, karena ada bantuan premi dari pemerintah pusat petani hanya membayar 20 persen saja. Dengan adanya bantuan premi, masih ada 5 petani Subur Makmur yang pada saat pendaftaran periode April - Juli 2017 belum ada uang untuk membayarkan premi.

\section{KESIMPULAN DAN SARAN}

Hasil penelitian ini menunjukan mayoritas petani subur makmur merupakan laki - laki dengan umur produktif, memiliki tanggungan keluarga 1 orang dan memiliki pengalaman $>10$ tahun dalam usahatani padi sedangkan pengalaman mengikuti AUTP hanya 2 kali musim tanam. Petani Subur Makmur hanya mengenyam pendidikan hingga tingkat Sekolah Dasar, memiliki luasan lahan sedang dengan pengahasilan yang termasuk kedalam klasifikasi menengah kebawah, merupakan petani penyewa, memiliki alasan mengikuti AUTP karena kebutuhan akan kemananan. Kendala ekonomi yang dihadapi yaitu adanya beberapa petani yang belum memiliki dana pada saat pendaftaran sehingga premi dibayarkan dahulu oleh ketua kelompok. Kendala teknis yang dialami yaitu petugas Jasindo kurang cepat dalam melakukan peninjauan ke Desa Karangmekar. 


\section{UCAPAN TERIMA KASIH}

Dalam penyusunan jurnal ini, tidak terlaksana tanpa bantuan, dorongan, bimbingan dan petunjuk dari berbagai pihak. Penulis mengucapkan terima kasih kepada dosen pembimbing, orang tua dan teman-teman yang sudah membantu penulis dalam menulis jurnal ini.

\section{DAFTAR PUSTAKA}

Amran, A et.al. 2017. Asuransi Pengayom Petani. Jakarta: Sekertariat Jenderal Kementerian Pertanian RI, hlm. 8, $24-25,28$.

Direktorat Jenderal Prasarana dan Sarana Pertanian Kementerian Pertanian RI.

2018. Pedoman Bantuan Premi AUTP. Jakarta, hlm. 4.

Irmayanti. 2010. Sistem Bagi Hasil Antara Pemilik Usahatani Lahan Sawah di Desa Bontotallasa, Kecamatan Simbang, Kabupaten Maros. Jurusan Sosial Ekonomi Pertanian Faperta Universitas Hasanudin Makasar.

Kamus Besar Bahasa Indonesia (KBBI). 2002. Pengertian Hambatan dan Kendala.

Kardoyo. 2017. Kebutuhan Manusia, Kelangkaan, dan Sistem Ekonomi. Kementrian Pendidikan dan Kebudayaan, hlm 4.
Kusno, Kuswarini et.al. 2018. Analysis of Rice Purchase Decision on Rice Consumer in Bandung City. IOP Conf. Series: Earth Environ. Sci

Nitisusastro, M. 2013. Asuransi dan Usaha Perasuransian di Indonesia. Bandung: CV. Alfabeta

Pasaribu, S. 2014. Penerapan Asuransi Pertanian di Indonesia. Badan Litbang Pertanian, hlm. 491.

Sajogyo. 1993. Agriculture and Industrialization in Rural Development in Dirkse et.al. KITVL Press. Leiden

Septian, Dandi. 2014. Perlindungan Petani Melalui Konsep Asuransi Pertanian Pada Gabungan Kelompok Tani Desa Argorejo, Kabupaten Bantul. Yogyakarta, diakses pada tanggal 4 April.

Sriyono. 2004. Karakteristik Demografi dan Tingkat Pendapatan Pemulung (Laskar Mandiri) Kasus di TPA Jatibarang Kora Semarang. Semarang: Jurusan Geografi Fakultas Ilmu Sosial UNNES.

Sudjana. 2002. Metode Statistika. Bandung: Tarsito

Tan, Kim H. 1991. Dasar - Dasar Kimia Tanah. Gajah Mada University Press: Jakarta.

Undang-Undang Nomor 20 tahun 2003 tentang Sistem Pendidikan Nasional. 